\title{
PENGARUH KUALITAS PRODUK TERHADAP KEPUTUSAN PEMBELIAN PRODUK SKINCARE KHUSUS PRIA DI ONLINE SHOP ELVICTO.ID
}

\author{
Aryfatul Khoir \\ Program Studi Magister Manajemen Universitas Tarumanagara \\ aryfatulkhoir@gmail.com \\ Chairy \\ Program Studi Magister Manajemen Universitas Tarumanagara
}

Masuk : 01-06-2020, revisi : 26-06-2020 diterima untuk diterbitkan : 26-06-2020

\begin{abstract}
Globalization is causing changes in various fields, starting from the transportation system and also the trading system. Online shopping grows unstoppable like mushrooms in the rainy season. The characteristics of consumers with modern social and educational backgrounds tend to like everything that is simple and fast, giving birth to a more modern trading system. It takes a marketing strategy that is appropriate and accurate with a data and analysis that is tested in a sales decision. A perception of quality is built as an initial introduction to a product, using public figures through various social media. The actual quality of the product in the end is something that must be proven to consumers according to the perception that is built as a commitment which then becomes positive reviews and reports that will return to the seller in the form of the intention to buy consumers.
\end{abstract}

Keywords: Quality Perception, Online Review, Purchase Intention

Abstrak: Globalisasi menyebabkan perubahan dalam berbagai bidang, mulai dari sistem transportasi dan juga sistem perdagangan. Online shopping bertumbuhan tak terbendung seperti jamur di musim hujan. Karakteristik konsumen dengan latar belakang sosial dan pendidikan yang modern cenderung menyukai segala hal yang bersifat simpel dan cepat, melahirkan sebuah sistem perdagangan yang lebih modern. Dibutuhkan strategi pemasaran yang sesuai dan akurat dengan sebuah data dan analisa yang teruji dalam sebuah keputusan penjualan. Sebuah persepsi kualitas dibangun sebagai awal pengenalan sebuah produk, dengan menggunakan para public figure melalui berbagai media sosial. Kualitas produk yang sebenarnya pada akhirnya adalah hal yang harus dibuktikan kepada para konsumen sesuai persepsi yang dibangun sebagai sebuah komitmen yang kemudian menjadi ulasan dan report positif dalam online review yang akan kembali kepada para penjual dalam bentuk intensi membeli para konsumen.

Kata kunci: Persepsi Kualitas, Online Review, Intensi Membeli

\section{PENDAHULUAN \\ Latar Belakang}

Globalisasi menyebabkan perubahan, terus berkembang jauh dari tahun-tahun sebelumnya. Globalisasi adalah suatu proses terbentuknya sistem organisasi dan komunikasi antar masyarakat di seluruh dunia untuk mengikuti sistem dan kaidah-kaidah tertentu yang sama (Selo Soemardjan, 2002:70). Ia merupakan sebuah fenomena dunia sehingga memiliki pengaruh yang sangat kuat terhadap setiap aspek kehidupan manusia.

Jika kita lihat fenomena saat ini, bukan hanya akun pribadi yang terdapat di Instagram, tetapi banyak juga terdapat akun-akun online shop yang memasarkan berbagai macam produk. Salah satu produk yang sangat ramai dipasarkan di instagram adalah pakaian dan skincare. Elvicto.id merupakan salah satu Online Shop yang menjual skincare pria dengan segmen remaja dan dewasa. Naik dan turunnya penjualan produk skincare di Online Shop elvicto.id 
tidak lepas dari proses keputusan pembelian yang dilakukan oleh konsumen. Secara umum ada banyak hal yang mempengaruhi konsumen dalam proses keputusan pembelian. Oleh karena itu, perlu dilakukan analisa terhadap hal-hal yang berpengaruh pada proses keputusan pembelian konsumen. Jika kualitas suatu produk mampu memberikan hasil atau kinerja yang sesuai bahkan melebihi dari apa yang diinginkan pelanggan, maka akan menarik minat konsumen (Kotler \& Keller, 2012).

Berdasarkan hal tersebut diatas, maka menarik untuk diteliti lebih lanjut tentang pengaruh kualitas produk, terhadap minat konsumen membeli produk elvicto.id.

\section{Tujuan Penelitian}

1. Untuk mengetahui pengaruh Online review terhadap Persepsi Kualitas produk di online shop elvicto.id

2. Untuk mengetahui pengaruh Online review terhadap Intensi Membeli produk di online shop elvicto.id

3. Untuk mengetahui pengaruh Persepsi Kualitas terhadap Intensi Membeli produk di online shop elvicto.id

\section{TINJAUAN PUSTAKA}

\section{Online review}

Online Customer Reviews (OCRs) adalah salah satu bentuk Word of Mouth Communication pada penjualan online (Filieri, 2014), Word of Mouth (WOM) merupakan salah satu bentuk komunikasi pemasaran dimana calon pembeli mendapatkan informasi tentang produk dari konsumen yang telah mendapatkan manfaat dari produk tersebut. Online review diberikan oleh konsumen kepada penjual sebagai penilaian atau rating penjual pada platform e-commerce yang bersangkutan.

\section{Persepsi Kualitas}

Menurut Kotler (2016:143), "Kualitas produk adalah kemampuan suatu barang untuk memberikan hasil atau kinerja yang sesuai, atau bahkan melebihi dari apa yang diinginkan pelanggan". Sedangkan menurut Mowen (2005:90), "Kualitas produk merupakan proses evaluasi secara keseluruhan kepada pelanggan atas perbaikan kinerja suatu barang atau jasa".

Sedangkan persepsi kualitas menurut Aaker (1997) adalah merupakan persepsi konsumen terhadap keseluruhan kualitas atau keunggulan suatu produk atau jasa layanan yang sama dengan maksud yang diharapkannya. Aaker (1997) juga menegaskan satu hal yang harus selalu diingat, yaitu bahwa persepsi kualitas merupakan persepsi para konsumen. Sehingga persepsi kualitas itu tidak dapat ditetapkan secara obyektif.

\section{Intensi Membeli}

Pengertian intensi secara sederhana adalah niat seseorang untuk melakukan perilaku tertentu. Fishbein dan Ajzen (1975) mendefinisikan intensi sebagai suatu kemungkinan subjektif yang melibatkan hubungan antara individu dengan perilakunya, dimana kemungkinan subjektif tersebut mengarahkan individu untuk berperilaku. Ajzen (2006) mengatakan bahwa intensi merupakan indikasi kesiapan seseorang untuk melakukan perilaku tertentu, dan ini dianggap sebagai anteseden langsung dari perilaku. Tujuannya didasarkan pada sikap terhadap perilaku, norma subjektif, dan control perilaku yang disadari.

\section{Penelitian Terdahulu}

Noi Sian Koh, Nan Hu, Eric K. Clemons, 2010 meneliti tentang Do Online reviews Reflect a Product's True Perceived Quality? dengan kesimpulan 85\% peserta survei 14,2\% yang memposting peringkat, $66,5 \%$ akan merespons jika mereka sangat menyukai film ini dan hanya 29,1\% akan melakukannya jika mereka sangat kecewa. Lily Harjati, Lusia Olivia Sabu, 2014 meneliti tentang Pengaruh Persepsi Kualitas Produk Terhadap Keputusan Pembelian The Body Shop, dengan kesimpulan Persepsi kualitas produk berpengaruh positif terhadap keputusan pembelian. Ahmad Farki, Imam Baihaqi, Mulia Wibawa, 2016 meneliti tentang Pengaruh Pengaruh Online Customer Review dan Rating Terhadap Kepercayaan dan Minat 
Pembelian pada Online Marketplace di Indonesia, dengan kesimpulan Review dan Rating adalah hal yang penting dalam online marketplace dan digunakan sebagai salah satu tools marketing utama.

\section{Hipotesis}

Hipotesis dalam penelitian ini adalah sebagai berikut:

H1 : Online Review berpengaruh positif terhadap Persepsi Kualitas suatu produk di online shop elvicto.id.

H2 : Online Review berpengaruh positif terhadap Intensi Membeli suatu produk di online shop elvicto.id

H3 : Persepsi Kualitas berpengaruh positif terhadap Intensi Membeli suatu produk di online shop elvicto.id

\section{METODOLOGI PENELITIAN}

\section{Jenis dan Waktu Penelitian}

Desain yang digunakan dalam penelitian ini adalah penelitian ex post facto. Metode ini kadang disebut kausal komparatif karena tujuannya adalah untuk menyelidiki hubungan sebabakibat antara variabel independen dan dependen.

\section{Populasi dan Sampel}

Berdasarkan observasi di CV Elite Center di Bekasi, jumlah konsumen antara bulan desember sampai januari 2020 berjumlah sekitar 200 konsumen. Konsumen inilah yang akan digunakan sebagai populasi. Dalam penelitian ini penulis menentukan jumlah sampel berdasarkan teori Arikunto (2010:134) dimana apabila populasi penelitian berjumlah kurang dari 100 maka sampel yang diambil adalah semuanya, namun apabila poplasi melebihi 100 maka sampel dapat diambil antara $10-15 \%$ atau $20-25 \%$ atau lebih. Dimana teknik yang dipergunakan dalam pengambilan sampel adalah dengan Random Sampling.

\section{Metode Analisis Data}

Metode analisis data yang dipergunakan adalah:

1. Uji Intrumen Penelitian

a. Uji Validitas, (Santosa 2005:145) adalah ukuran yang menunjukkan sejauh mana instrument pengukur mampu mengukur apa yang ingin diukur.

b. Uji Reliabilitas, (Santosa 2005:147) adalah ukuran instrument yang menunjukkan konsistensi dari alat ukur dalam mengukur gejala yang sama di lain kesempatan.

2. Uji asumsi klasik, dilakukan dalam upaya untuk memperoleh hasil analisa regresi yang sahid (valid).
a. Uji Normalitas, analisis grafik (normal P-P plot) regresi
b. Uji Multikolinearitas
c. Uji Heteroskedastisitas
d. Uji Analisis Regresi Berganda: merupakan persamaan regresi dengan menggunakan dua atau lebih variabel independen.

3. Pengujian Hipotesis, Priyatno 2011:

a. Analisis Adjusted R2, menguji prosentase pengaruh variabel bebas secara bersamasama terhadap variabel terikat.

b. Uji F, menguji pengaruh variabel bebas secara bersama-sama terhadap variabel terikat.

c. Uji t, mengetahui pengaruh variabel independen secara parsial terhadap variabel dependen.

4. Analisa Baron dan Kenney (1986)

Baron dan Kenny (1986) menyebut suatu variabel disebut mediator jika variabel tersebut ikut mempengaruhi hubungan antara variabel prediktor (independen) dan kriterion (dependen). 


\section{HASIL DAN KESIMPULAN}

\section{Uji Instrumen Penelitian}

a. Uji Validitas:

Berdasarkan hasil penelitian untuk setiap butir soal pada variable Online review, Persepsi kualitas dan variabel intensi membeli ternyata menunjukan bahwa semua nilai $\mathrm{r}$ hitung lebih besar dari $\mathrm{r}$ table $(0,294)$ yaitu antara $0,564-0,818$ sehingga dapat dinyatakan valid.

b. Uji Reliabilitas

Berdasarkan data dari tabel 1, diketahui Alpha Cronbach's adalah sebesar 0.758 lebih besar dari 0.600, maka kuesioner yang disebarkan adalah reliabel.

\section{Tabel 1}

\section{Hasil Uji Coba Reliabilitas Online review}

\begin{tabular}{|c|c|c|}
\hline Cronbach's Alpha & $\begin{array}{c}\text { Cronbach's Alpha Based } \\
\text { on Standardized Items }\end{array}$ & N of Items \\
\hline, 758 &, 769 & 6 \\
\hline
\end{tabular}

Berdasarkan data dari tabel 2, diketahui nilai Alpha Cronbach's adalah sebesar 0.893 lebih besar dari 0.600, maka kuesioner yang disebarkan adalah reliabel.

\section{Tabel 2}

\section{Hasil Uji Coba Reliabilitas Persepsi Kualitas}

\begin{tabular}{|r|r|r|}
\hline Cronbach's Alpha & $\begin{array}{c}\text { Cronbach's Alpha } \\
\text { Based on } \\
\text { Standardized Items }\end{array}$ & N of Items \\
\hline, 897 & 12 \\
\hline
\end{tabular}

Berdasarkan data dari tabel 3, diketahui nilai Alpha Cronbach's adalah sebesar 0.828 lebih besar dari 0.600 , maka kuesioner yang disebarkan adalah reliabel.

\section{Tabel 3}

\section{Hasil Uji Coba Reliabilitas Intensi Membeli}

\begin{tabular}{|r|r|r|}
\hline Cronbach's Alpha & $\begin{array}{c}\text { Cronbach's Alpha } \\
\text { Based on } \\
\text { Standardized Items }\end{array}$ & N of Items \\
\hline, 828 &, 841 & \\
\hline
\end{tabular}

\section{Uji Asumsi Klasik}

a. Uji normalitas

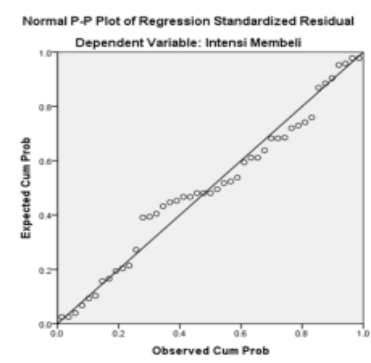

Gambar 1

Uji Normalitasgrafik (normal P-P plot) regresi, terdistribusi secara normal b. Uji Multikolinearitas

Tabel 4

Hasil Uji Multikolinearitas, VIF $>10$ \& T>0,1, Bebas Multikolinearitas

\begin{tabular}{|l|r|r|c|}
\hline \multirow{2}{*}{ Model } & \multicolumn{2}{|c|}{ Collinearity Statistics } & \multirow{2}{*}{ Keterangan } \\
\cline { 2 - 3 } & \multicolumn{1}{|c|}{ Tolerance } & \multicolumn{1}{c|}{ VIF } & \\
\hline 1 (Constant) & .950 & 1,053 & Tidak terjadi \\
\cline { 2 - 3 } Online Review & .950 & 1,053 & Tidak terjadi \\
\hline \multicolumn{2}{|l|}{ Persepsi Kualitas } & &
\end{tabular}


c. Uji Heteroskedastisitas

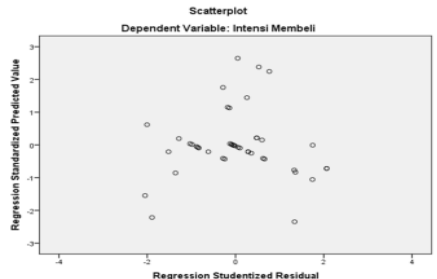

Gambar 2

Hasil Uji Heteroskedastisitas, tidak terjadi masalah Heteroskedastisitas

d. Analisis Regresi Berganda

Tabel 5

Regresi

\begin{tabular}{|c|l|l|l|}
\hline \multicolumn{2}{|c|}{ Model } & \multicolumn{2}{c|}{ Unstandardized Coefficients } \\
\cline { 3 - 4 } \multicolumn{2}{|c|}{} & B & Std. Error \\
\hline \multirow{3}{*}{1} & (Constant) & 1,319 & 2,352 \\
\cline { 2 - 4 } & Online Review &,- 040 &, 076 \\
\cline { 2 - 4 } & Persepsi Kualitas &, 411 &, 038 \\
\hline
\end{tabular}

$\mathrm{Y}=1,319-0,040 \mathrm{X}_{1}+0,411 \mathrm{X}_{2}$,

Online review dan persepsi kualitas secara parsial berpengaruh signifikan terhadap intensi membeli

\section{Uji Hipotesa}

a. Analisis koefisien determinasi (Adjusted R2)

Tabel 6

Koefisien Determinasi

\begin{tabular}{|l|r|r|r|}
\hline Model & \multicolumn{1}{|c|}{ R } & \multicolumn{1}{|c|}{ R Square } & Adjusted R Square \\
\hline 1 & $.859^{\mathrm{a}}$ &, 738 &, 725 \\
\hline
\end{tabular}

Besar nilai koefisien determinasi diperoleh melaui tabel di bawah dimana diperoleh perhitungan SPSS adalah sebesar 0,738. Hal ini menunjukan bahwa 73,8 \% keragaman variabel Intensi Membeli Elvicto.id disebabkan oleh keragaman variabel Online review (X1) dan Persepsi Kualitas (X2), sedangkan sisanya sebanyak 26,2 \% disebabkan oleh faktor lain yang tidak di teliti oleh penulis.

b. Uji F, uji variabel online review dan persepsi kualitas secara bersama terhadap intensi membeli

Tabel 7

Anova

\begin{tabular}{|c|c|c|c|c|c|c|}
\hline \multicolumn{2}{|c|}{ Model } & $\begin{array}{l}\text { Sum of } \\
\text { Squares }\end{array}$ & $\mathrm{df}$ & Mean Square & $\mathrm{F}$ & Sig. \\
\hline \multirow[t]{3}{*}{1} & Regression & 149.583 & 2 & 74.792 & 59.027 & $.000^{\mathrm{b}}$ \\
\hline & Residual & 53.217 & 42 & 1.267 & & \\
\hline & Total & 202.800 & 44 & & & \\
\hline
\end{tabular}

Berdasarkan nilai Sig, dimana $0,000<0,05$ maka online review dan persepsi kualitas secara bersama berpengaruh signifikan terhadap intensi membeli.

c. Uji t, uji variabel independen secara parsial

\section{Tabel 8}

\section{Koefisien}

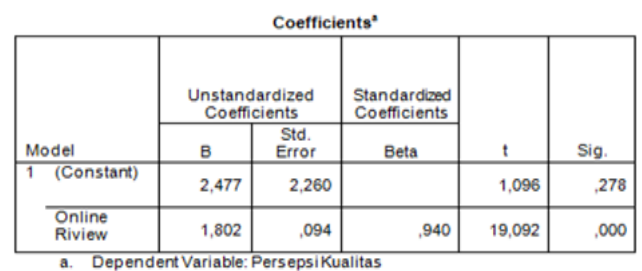

Dengan demikian Online Review berpengaruh signifikan terhadap Persepsi Kualitas atau $a \neq 0$ 


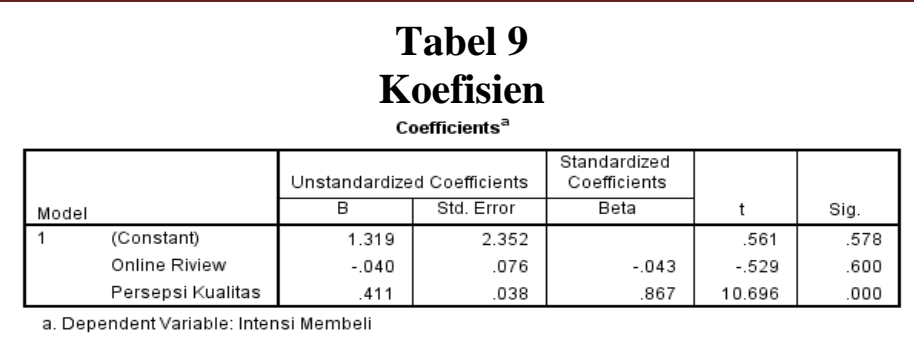

Berdasarkan nilai sig dimana 0,600>0,05, maka Online review tidak berpengaruh signifikan terhadap intensi membeli. Berdasarkan nilai sig dimana $0,000<0,05$, maka persepsi kualitas berpengaruh signifikan terhadap intensi membeli

\section{Analisa Baron dan Kenney (1986)}

Berdasarkan kepada hasil uji hipotesa di atas, mediasi Baron dan Kenney tidak terpenihi karena jalur c yaitu Online Review (X) signifikan mempengaruhi Intensi Membeli (Y) tidak terpenuhi. Metode ini banyak dikritik karena hanya menganalisis model mediator yang komplit alias sempurna. Menurut para pengkritiknya, yang diperlukan hanyalah jalur a dan jalur b saja. Jalur c dan jalur c' hanyalah untuk menguji apakah model mediatornya sempurna ataukah tidak.

\section{Kesimpulan}

1. H1 dapat diterima dimana Online Review berpengaruh positif terhadap Persepsi Kualitas suatu produk di online shop elvicto.id.

2. H2 ditolak dimana Online Review tidak berpengaruh positif terhadap Intensi Membeli suatu produk di online shop elvicto.id

3. H3 dapat diterima dimana Persepsi Kualitas berpengaruh positif terhadap Intensi Membeli suatu produk di online shop elvicto.id

\section{Saran}

Saran kepada Elvicto.id sebagai berikut:

1. Meningkatkan Kualitas produk skincare khusus pria dan seluruh produk Elvicto.id.

2. Tetap melakukan dan meningkatkan promosi melalui media social dengan menggunakan komunitas para public figure sebagai media penjualan.

3. Memperluas jangkauan pasar dan membuat lebih banyak varian produk terutama terkait dengan fasion dan gaya hidup.

4. Menyusun dan melakukan program jangka panjang berdasar kepada kajian para ahli sebagai bentuk ekspansi dan pertahanan.

5. Selalu melakukan evaluasi jangka pandek terhadap kualitas produk dan isu - isu trend belanja online.

\section{DAFTAR PUSTAKA}

Aaker, D. A. (1997). Manajemen Ekuitas Merek: Memanfaatkan Nilai dari Suatu Merek (Cetakan Pertama). Jakarta: Mitra Utama.

Amalia, S. \& Gani, I. (2015). Alat Analisis Data: Aplikasi Statistik untuk Penelitian Bidang Ekonomi dan Sosial. Yogyakarta: CV Andi Offset.

Azwar, S. (1997). Metode Penelitian. Yogyakarta: Pustaka Pelajar.

Farki, A., Baihaqi, I., \& Wibawa, B. M. (2016). Pengaruh online customer review dan rating terhadap kepercayaan dan minat pembelian pada online marketplace di Indonesia.

IMC Spiegel Research Center. How Online Reviews Influence Sales https://spiegel.medill.northwestern.edu/online-reviews/

iResearch. (2014). iResearch Quarter Report [EB/OI]. http://report.iresearch.cn/html/20141105/241068.shtml CNNIC (2015) The 35 th

Purnomo, D. (2015). Statistik Sosial dan Aplikom. Salatiga: Widya Sari Press Salatiga

Zan, M., Yan-Fei, L., \& Peng, F. (2015). Effect of Online reviews on Consumer Purchase Behavior. 